\title{
Racism, Resentment, and Regionalism: The South and the Nation in the 2008 Presidential Election
}

\author{
Joseph A. Aistrup
}

This paper assesses the influences racial resentment and racial stereotypes on Southern and non-Southern white, Asian, and Hispanic voters in the 2008 presidential election. I use logistic regression to test the hypotheses that racial resentment and racial stereotypes influenced support for McCain and that the influence of these two variables is greater in the South than in the non-South. The findings suggest that racial resentment's influence extends across both regions but that the affects of racial stereotypes is confined to the South. The analysis is replicated for U.S. House elections in 2008, finding that the impact of racial resentment and racial stereotypes is insignificant in both regions. In 2008, the influences of racism, resentment and regionalism on voting are confined to the presidential level.

There is a growing chorus of studies suggesting that Barack Obama did not garner as many votes as a white Democrat presidential nominee would have under similar electoral conditions. Sniderman and Stiglitz (2008) were the first to suggest that Obama may have underperformed. Using indicators of racial prejudice developed by the authors, they found that self-identified Democrats who were high on the racial prejudice scale were significantly less likely to vote for Obama, whereas Republicans, no matter what their level of racial prejudice were all equally unlikely to support Obama. Carl Klarner's (2008) analysis also found evidence that Obama underperformed. Using methods similar to ecological regression, his findings suggest that Obama should have obtained roughly 55 percent of the popular vote compared to 52.9 percent. Michael Lewis-Beck, Charles Tien, and Richard Nadeau's (2010) economic model for predicting presidential voting support echoes Klarner's findings. They found that Obama underperformed by at least 5 percent of the popular vote. Moreover, they tie this performance gap to negative attitudes about blacks, specifically with the perception by some voters that if elected Obama would institute policies that favor blacks. Most recently, Spencer Piston (2010) and Aistrup, Kisangani, and Piri (2010b) added to this chorus. Piston found that negative stereotypes about blacks in comparison to whites significantly lowered the probability of white voters supporting Obama, while Aistrup et al, showed that racial resentment significantly affected the probability of supporting Obama for white voters in the South. However, not all studies concur with these conclusions.

JOSEPH A. AISTRUP is a professor of political science at Kansas State University.

The American Review of Politics, Vol. 32, Summer, 2011: 131-154

(C)2011 The American Review of Politics 
Ansolabehere and Stewart (2009) suggest that Obama benefited from a racial dividend through increased turnout of blacks and Hispanic voters (compared to 2004) who voted overwhelming for him. Extrapolating from exit poll data, they conclude that McCain would have won if blacks and Hispanics would have voted at the same levels as 2004. Even though Grose, Husser, and Yoshinaka (2010) find that race influenced presidential vote choice in 2010 more so than any election since 1996, they note that there were a number of other independent variables that had a greater effect.

This paper builds off the work of Piston (2010) by assessing the influences racial attitudes on Southern and non-Southern white, Asian and Hispanic voters in the 2008 presidential election. I use logistic regression to test the hypotheses that higher levels of racial resentment and negative stereotypes about blacks increased the likelihood of supporting McCain and that this likelihood is greater in the South than in the non-South. The findings show that racial resentment affected presidential voting patterns in the South and non-South, but that negative racial stereotypes only influenced the voting patterns of southerners. I also tested an analogous model for the U.S. House contests in 2008, finding that racial attitudes had no impact. The conclusion discusses the significance of these findings as it relates to the three Rs, racism, resentment and regionalism.

\section{The Three Rs: Racism, Resentment, and Regionalism}

The research questions for this study come from the interaction among three converging conditions, all of which collided in the 2008 U.S. presidential election. The first condition is the most obvious; the unprecedented and historic introduction of race into the 2008 presidential contest. Since World War II, racial issues have been a key aspect of the 1964 and 1968 presidential contests (Sundquist 1983), and a more subdued component of the 1980, 1984 and 1988 elections (Edsall and Edsall 1992; Black and Black 2002; Aistrup 1996). Obama, as the first African American to win a major party's presidential nomination, brought the race of the candidate, as opposed to racial issues, front and center. Although unprecedented at the presidential level, African Americans have been running in congressional and statewide contests for decades. Qualitative studies of black candidates who won in majority white constituencies suggest that they share several common attributes. They tend to be career politicians, moderate, race-neutral, but tough on crime. Despite being race-neutral they find a quiet but effective way to mobilize the black communities in their state to turnout in high numbers. This high turnout is necessary to counter balance the loss of white voters at the polls (Frederick and Jeffries 2009; Jeffries 1999). 
With the exception of the Reverend Jeremiah Wright controversy, ${ }^{1}$ which is a major exception that almost derailed Obama's march to the Democratic nomination, Obama and his handlers followed this prescription for victory. When combined with Obama's eloquent speaking ability, which transcends racial boundaries, and his juggernaut grassroots campaign organization, he was able to extend the field of battle into states like Indiana, North Carolina, and Virginia, states that other Democratic presidential candidates usually abandoned shortly after the convention. His opponent, John McCain, also contributed to Obama's efforts to be race-neutral. McCain did not explicitly or implicitly use the race card, even though he could have easily made an issue of the Reverend Wright controversy during the general election campaign. Except for media outlets reminding voters that Obama would be the "first black elected president," ${ }^{2}$ the general election campaigns of both candidates steered clear of race (Piston 2010). This created an electoral environment where if race mattered in the choice between Obama and McCain, Obama's African American heritage would be the primary triggering mechanism. Obama and McCain did their parts to make this a "postracial” campaign (Piston 2010).

This segues to the second converging condition: The continuing existence of racially based attitudes in the U.S. Historically, racial prejudice in the form slavery and then Jim Crow laws kept blacks from experiencing the freedoms that white Americans enjoyed. Even though over 40 years has passed since the passage of the civil rights and voting rights acts, which put an end to de jure segregation, racially based attitudes towards African Americans still persist among whites. The question is whether these racially based attitudes translate into political behavior. Over the years, the findings on this issue have been inconsistent. For example, Terkildsen (1993, 1032) used an experimental research design to build a convincing case that the skin color of the candidate matters for white voters. She found "that black candidates were penalized by white voters based on the candidate's race, skin color, and individual levels of racial prejudice.” Moreover, her findings suggest that the darker the skin tone of the black candidate, the more likely white voters will process racial information. Alternatively, Colleau and her colleagues (1990) used an experimental research design to test McConahay's idea (1986) that negative attributions to black candidates only emerge when ambiguous or negative qualities are present. They found that while race is a source of discrimination, black candidates were evaluated higher, not lower than the other candidates. Similarly, Highton (2004) using exit poll data from Congressional elections in 1996 and 1998, found no evidence that white voters penalized black candidates for their race.

Racially based attitudes come in a variety of shades. ${ }^{3}$ Failure to recognize this reality has been the source of much controversy within political 
science over the proper measurement of racial attitudes. Explicit racial prejudice is its most insidious form. This is the belief that members of another race are inherently inferior based on "faulty and inflexible generalizations" (Allport 1988). The survey evidence suggests that explicit forms of prejudice have decreased in the U.S. (Peffley and Shields 1996; Cotter et al. 2006), with the caveat that these prejudicial attitudes are difficult to uncover because respondents do not like to reveal socially unacceptable answers to surveyors. As the more explicit forms of racial prejudice have declined and/or become tough to measure, analysts have turned their attention to racially based opinions that may or may not rise to the level of racial prejudice. Referred to originally as "symbolic racism" and later revised to "racial resentment" (Stoker 1998; Kinder and Sears 1981; McConahay and Hough 1976; McConahay 1986; Sears 1988), this construct assesses the feelings that African Americans fail to live up to the American work ethic and wrongfully seek favorable treatment to redress the effects of discrimination.

Compared to measures of racial resentment, measures of explicit racial prejudice have not had as successful of a track record of predicting whites' voting behavior in racially charged elections. The most extensive research record was developed in the 1970s and 1980s centered on Tom Bradley's campaigns for mayor of Los Angeles and then governor of California. These studies found that racial resentment predicted white votes for Bradley's opponents (Kinder and Sears 1981; McConahay and Hough 1976; Sears and Kinder 1971), but that measures of explicit racism had a minor impact (Citrin et al. 1990). Similarly, racial resentment was also useful for explaining votes in other types of elections where race played a prominent role. Susan Howell found that racial resentment was "by far the most influential factor" in explaining the votes for the former Klansman David Duke in his three statewide elections in the early 1990s in Louisiana $(1994,190)$.

However, explicit racism may have made a come back during the 2008 presidential election. Spencer Piston (2010) showed that racial prejudice, in the form of negative stereotypes about blacks in comparison to whites, significantly lowered the probability of white voters supporting Obama.

Given Obama's race, this research suggests that racial attitudes may have translated into political behavior during the 2008 presidential election, even though McCain did nothing in his campaign to make Obama's race a factor. I expect that Obama's race will be enough to trigger significant relationships between racially based attitudes-both racial prejudice and racial resentment-and white support of McCain versus Obama.

The historical crossroad for the intersection between race and politics in U.S. is in the South, the home of the Confederacy, the epicenter of Jim Crow segregation, the civil rights movement, and white resistance to integration. To be fair, this history is rather dated. In fact, much has changed in the 
South due to a variety of causes but most importantly the large migration of non-natives in the post-WWII/air conditioned era (Black and Black 1987). This population shift helped to fuel the development of modern urban centers like Dallas, Houston, Atlanta, Charlotte, Northern Virginia, and Miami and helped to transform the old South into the new South. This transformation has led some scholars to question the continued distinctiveness of the region (Shafer and Johnston 2006). Thus, the third converging condition can be translated into the following research question: Are there substantial political differences between voters in the South and the North, or more accurately the "non-South," such that one can expect the impact of racial attitudes on voting in the 2008 presidential contest to be greater in the South than the non-South.

If the 2008 presidential election took place in the old South in 1950, the answer would be an unequivocal yes. V.O. Key used presidential voting patterns of the eleven Confederate states to show that the South's presidential voting patterns were distinctive $(1949,10)$. Sixty years after Key's observations, the answer is anything but unequivocal. On one side of this divide are studies comparing the attitudes and opinions of Southerners to non-Southerners (see Cotter et al. [2006] for a review of this literature), all of which suggests the new South remains distinctive, although maybe not as distinctive as in the past. This literature finds that southerners are more inclined to support school prayer (Feig 1990) and less inclined to support sex education, abortion rights, and gay rights (Rice et al. 2002). Southerners range from slightly more conservative than non-southerners (Beck and Lopatto 1982; Cotter and Stovall 1990; Carmines and Stanley 1990) to considerably more conservative (Black and Black 1987; Wright et al. 1985) depending on data sources. In some survey years, southerners are found to be more conservative on government spending for the poor, education and health care, but in other survey years, this is not the case (Rice et al. 2002). Even though the racial attitudes of southerners have softened since the days of de jure segregation, white southerners tend to be the most conservative on the issues of school integration and affirmative action, and have the most negative attitudes about the civil rights movement and blacks (Schuman et al. 2005).

There are also a subset of public opinion studies that analyze the changing nature of party identification in the South and non-South using racial resentment as a predictor. Both Knuckey (2005) and Valentino and Sears (2005) find that racial resentment tends to fuel the rise in white Republican identifiers in the South more so than the non-South. In addition, Valentino and Sears (2005) find that racial resentment structures presidential voting preferences up to 2000 more so in the South than the non-South. On the other hand, Cowden (2001) finds that a racial issues axis now cleaves both 
Southerners and non-Southerners in a similar manner, suggesting there is little difference between voters in the South and non-South.

The controversy among southern politics scholars is most notable when analyzing the voting patterns. Some scholars find distinctive patterns of office holding and voting when comparing the South to other regions (Bullock et al. 2006; Black and Black 2002) while others find that the South's regional patterns of voting are no longer exceptional in congressional (Shafer and Johnston 2006, 189-99) and presidential elections (Aistrup 2010a). The results of the 2008 presidential election underscore this controversy. In the Northeast, Midwest, and West, Obama tallied 59 percent, 54 percent, and 57 percent, respectively. Whereas in the southern states, Obama managed only 46 percent, despite carrying by a slim margin Florida, Virginia, and North Carolina, three of the southern states that have experienced much population change over the past 50 years. This regional disparity reignites an on-going controversy regarding the exceptionalism of the South, especially on matters associated with racially based attitudes (Key 1949; Bass and DeVries 1976; Bullock et al. 2005; McKee 2009; Shafer and Johnston 2006).

All of this suggests that Obama's race will trigger the reemergence of old South. Thus, when compared to racially based attitudes of non-South whites, these attitudes among Southern whites will have a greater influence on the odds of supporting McCain versus Obama.

\section{Data Sets, Measurement, and Model}

The data for this study come from the ANES 2008-2009 Panel Study (ANES 2010). This study is an internet based panel survey administered by Knowledge Networks. ${ }^{4}$ I use this data set versus the American National Election Studies, 2008: Pre and Post Election Surveys (ANES 2009) to assuage issues with the social desirability of answering sensitive questions dealing with race via face to face interviews. Piston $(2010,437)$ showed that respondents were more likely to answer race based questions about stereotypes in a socially acceptable manner if the questions were administered in a face to face personal interview versus an Audio Computer-Assisted SelfInterviewing (ACASI) system. The internet based panel survey is also a selfadministered survey. Given Piston's findings, answers to racially based questions on this internet survey are less likely to be plagued by social desirability concerns.

The dependent variable is presidential vote choice, coded 1 if the respondent voted for McCain and 0 if the respondent voted for Obama. This question was administered in Wave 11, shortly after the November 2008 elections. Because over 90 percent of African Americans support Demo- 
cratic presidential candidates and this percentage may have been higher for Obama, I exclude blacks from this analysis. The vast majority of these respondents are white, including those who consider themselves to be Hispanic. Thus, for the sake of brevity, I refer to the sample as "white voters." All analyses are weighted.

I include two indexes of racial attitudes. The first is meant to tap into explicit racism. Similar to Piston (2010) I use indicators of stereotypes, but the question wording for the internet panel survey varies from the traditional wording used in ANES's face to face surveys. Under the traditional format, respondents are asked to rate most people in a racial group on a seven point scale ranging from "hardworking" to "lazy" and then "intelligent" to "unintelligent." In the panel survey, respondents answer "How well does '[insert characteristic]' describe most [insert racial or ethnic group]?” on a five point scale ranging from "extremely well" to "not well at all." To replicate Piston's work, I use the questions about blacks and whites dealing with "intelligent at school," "lazy," and "hardworking." Similar to Piston, I subtract the ratings for blacks from the ratings of whites for these three characteristics. Thus, if a respondent answers "not well at all" to blacks are hardworking and the same for whites, the difference would be 0 . But, if instead the respondent answers for whites "extremely well," the difference would be +4 , suggesting a negative stereotype against blacks. I added the differences on these three topics together and divided it by three, leaving an indicator that ranges between a low of -4 to a high of +4 , where -4 represents explicit stereotypes against whites and a +4 represents explicit stereotypes against blacks.

The other indicator of racial attitudes is racial resentment, which is measured by summing the responses to four questions. On a five point scale ranging from strongly agree to strongly disagree, respondents are asked: 1 ) "Irish, Italians, Jewish, and many other minorities overcame prejudice and worked their way up. Blacks should do the same without any special favors." 2) "Over the past few years blacks have gotten less than they deserve." 3) "It's really a matter of some people not trying hard enough; if blacks would only try harder they could be just as well off as whites." 4) "Generations of slavery and discrimination have created conditions that make it difficult for blacks to work their way out of the lower class.” Previous research has shown that these indicators are valid and reliable (Henry and Sears 2002). The principle components factor analysis shows that these four items load onto one factor. The Cronbach's Alpha for the index is .698. These four items are added together so that conservative racial attitudes reflect higher values. The additive index ranges between -8 and +8 .

For some, the construct of racial resentment is controversial. Sniderman and Tetlock (1986) showed that some of the statements in the original index 
only measured "government intervention on racial matters" which had "little or nothing to do with prejudice" (Feldman and Huddy 2005; Schuman 2000; Sniderman and Hagen 1985; Sniderman and Piazza 1993). Even after a revision of these questions in 1986, there remains a correlation between higher racial resentment scores and conservatism in the U.S. (Kinder and Mendelberg 2000). As these scholars note, conservatives simply oppose, as a matter of principle, the use of government to address issues of this nature, racially based or otherwise. For this reason, ideology is an important control variable for any analyses that include racial resentment as an independent variable. Ideology will absorb any variance due to respondents' being principled conservatives versus individuals who score high on the racial resentment index due to other concerns.

Even with this control for ideology, some scholars argue there is still a broader theoretical measurement question associated with racial resentment: Is it an indicator of racial prejudice or is it simply another manifestation of ideology? For this study, it is neither. Rather, I consider racial resentment as simply a continuum focused on valid political issues regarding the state of African Americans as a group in the U.S. No doubt that these racially based attitudes are correlated with partisanship and ideology just like any other set of issues dealing with economics, the War in Iraq, gun control, welfare, etc. As with any other valid indicator of political opinion, proper controls for partisanship and ideology should be included or the results of the analysis will be biased.

Table 1 shows the frequencies and summary statistics for racial biased stereotypes and racial resentment indices. For racial biased stereotype, most of the respondents are clustered between +1 and -1 , with a plurality of whites at zero. Racial resentment has greater variation than racially biased stereotypes. The scores tend to be clustered on the positive side of the index, toward higher levels of racial resentment.

I conducted a breakdown of the racially biased stereotypes and racial resentment indexes by region. Given the previous literature showing that southerners tend to be more conservative on racially based issues (Cotter et al. 2006), the breakdown should show that southerners have higher values on both indices when compared to respondents from the non-South. The findings correspond with these expectations. For southern whites, the average stereotype score is .221, whereas for the non-South it is .114 ( $\mathrm{p}=.004)$. The difference is even greater on the average racial resentment score. For respondents in the non-South, the average is 1.21 , while in the South it is $2.36(\mathrm{p}=.0000)$.

By including an indicator of explicit racial prejudice (stereotypes) and racial resentment together in the same equation, I follow the path of Citrin et al. (1990) who used both types of indicators in their analysis of votes for 
Table 1. Frequencies for Racial Attitudes

\begin{tabular}{|c|c|c|c|c|c|}
\hline & Value & $\begin{array}{l}\text { Stereotype } \\
\text { Frequency }\end{array}$ & Percent & $\begin{array}{c}\text { Cumulative } \\
\text { Percent }\end{array}$ & \\
\hline \multirow{21}{*}{ White Stereotype } & -3.33 & 1 & 0.05 & 0.05 & \\
\hline & -2.67 & 1 & 0.05 & 0.1 & \\
\hline & -2.33 & 2 & 0.1 & 0.19 & \\
\hline & -2.00 & 5 & 0.24 & 0.44 & \\
\hline & -1.67 & 6 & 0.29 & 0.73 & \\
\hline & -1.33 & 26 & 1.26 & 1.99 & \\
\hline & -1.00 & 67 & 3.26 & 5.25 & \\
\hline & -0.67 & 162 & 7.88 & 13.13 & \\
\hline & -0.33 & 315 & 15.32 & 28.45 & \\
\hline & 0.00 & 734 & 35.7 & 64.15 & Avg.=.139 \\
\hline & 0.33 & 267 & 12.99 & 77.14 & Median=0 \\
\hline & 0.67 & 199 & 9.68 & 86.82 & Std Dev $=.728$ \\
\hline & 1.00 & 106 & 5.16 & 91.97 & \\
\hline & 1.33 & 61 & 2.97 & 94.94 & \\
\hline & 1.67 & 35 & 1.7 & 96.64 & \\
\hline & 2.00 & 31 & 1.51 & 98.15 & \\
\hline & 2.33 & 16 & 0.78 & 98.93 & \\
\hline & 2.67 & 11 & 0.54 & 99.46 & \\
\hline & 3.00 & 4 & 0.19 & 99.66 & \\
\hline & 3.33 & 3 & 0.15 & 99.81 & \\
\hline & 3.67 & 3 & 0.15 & 99.95 & \\
\hline Black Stereotype & 4.00 & 1 & 0.05 & 100 & \\
\hline \multirow[t]{4}{*}{ Total } & 2056 & 100.00 & & & \\
\hline & & Racial & & & \\
\hline & & Resentment & & Cumulative & \\
\hline & Value & Frequency & Percent & Percent & \\
\hline \multirow[t]{16}{*}{ Low Resent } & -8 & 24 & 1.16 & 1.16 & \\
\hline & -7 & 28 & 1.35 & 2.51 & \\
\hline & -6 & 45 & 2.17 & 4.69 & \\
\hline & -5 & 51 & 2.46 & 7.15 & \\
\hline & -4 & 76 & 3.67 & 10.83 & \\
\hline & -3 & 104 & 5.03 & 15.85 & \\
\hline & -2 & 114 & 5.51 & 21.36 & \\
\hline & -1 & 138 & 6.67 & 28.03 & Avg.= 1.496 \\
\hline & 0 & 274 & 13.24 & 41.28 & Median=1 \\
\hline & 1 & 189 & 9.13 & 50.41 & Std Dev=3.86 \\
\hline & 2 & 198 & 9.57 & 59.98 & \\
\hline & 3 & 149 & 7.2 & 67.18 & \\
\hline & 4 & 174 & 8.41 & 75.59 & \\
\hline & 5 & 145 & 7.01 & 82.6 & \\
\hline & 6 & 124 & 5.99 & 88.59 & \\
\hline & 7 & 94 & 4.54 & 93.14 & \\
\hline High Resent & 8 & 142 & 6.86 & 100 & \\
\hline Total & 2069 & 100.00 & & & \\
\hline
\end{tabular}


Bradley in the 1980s California gubernatorial contests. This approach varies from Piston (2010) who used only an index of stereotypes to predict the voting behavior of whites in the 2008 presidential election and Aistrup, Kisangani, and Piri (2010b) who used only an indicator of racial resentment to do the same in the South. Including both, allows the analysis to tap into two different components of racial attitudes: explicit racism and attitudes toward the condition of African Americans as a group in the U.S. Thus, this model is more fully specified than either of these two previous studies.

However, including both indicators of racial attitudes together in the analysis could pose some problems because the two indices will have some shared variance. Given the previous research, this may cause racial resentment to drown out the effects of racially biased stereotypes. To resolve this issue, it is necessary to understand the relationship between the two indices. A respondent who holds a number of stereotypes against blacks is also very likely to score high on the racial resentment index. On the other hand, it is not necessarily the case that a respondent who scores high on racial resentment will also score high on stereotypes against blacks. This means that by definition, overt racism trumps racial resentment and any shared variation between the two indices is really owned by the racial biased stereotypes index.

To remove this shared variation between racially biased stereotypes and the racial resentment index, I regress stereotypes on racial resentment and use the unstandardized residuals from the regression as the indicator for racial resentment. This effectively removes the shared variation between the two indices, allowing each to account for its own independent influence on the probability of voting for McCain.

The main foci of this analysis are the influences of stereotypes and racial resentment on the 2008 presidential vote choice. The other independent variables that are included in the analysis are chosen for the purposes of fully specifying the model of presidential vote choice. For this analysis, party identification and ideology are the most important controls. Party identification is a durable measure of party support (Campbell et al. 1960; Campbell 1966; Miller and Shanks 1996), especially in the South where those identifying themselves as Republican vote more cohesively for Republican candidates at all election levels (Bullock et al. 2005; Knuckey 2005; Shaffer et al. 2000). In addition, previous research shows that party identification and racial resentment are significantly related (Knuckey 2005; Valentino and Sears 2005).

Ideology has also been shown to predict vote choice (Abramowitz and Saunders 1998), and as noted earlier, some contend that conservative ideological predisposition may be the real cause of voters favoring Republican 
candidates versus conservative racial resentment attitudes (Feldman and Huddy 2005; Schuman 2000; Kinder and Mendelberg 2000; Sniderman and Hagen 1985; Sniderman and Piazza 1993). Including both partisanship and ideology means that this model seeks to understand the influence of stereotypes and racial resentment after controlling for these other two variables. In this sense, the analysis tilts toward Type II error.

The other independent variables are retrospective evaluations, represented by President Bush's job approval ratings (Fiorina 1981), religious values, as represented by church attendance (Green et al. 2002; Green et al. 2003; Knuckey 2006; Schneider 1998; Smith 1997; Oldfield 1996), economic class represented by education level (Brewer and Stonecash 2001; Shafer and Johnston 2006), and age (Schuman et al. 1997; Virtanen and Huddy 1998). I control for the influences of ethnicity by including a dummy variable representing white-Hispanics.

Party identification, ideology, Bush approval, age, income, education, and church attendance are coded so that the distribution of each is centered around 0 , where 0 is defined as the median of the distribution or the value of the middle point of the scale. This aids in the interpretation of the constant, which represents the logged odds of a McCain vote when all of the independent variables are held constant at 0 (Jaccard 2001, 30-34).

Because the dependent variable is dichotomous, I use logistic regression to assess the affects of each independent variable on the logged odds of voting for a Democratic presidential candidate (Long and Freese 2006, 177). In addition to coefficients and Z-scores, each table reports the factor change in the odds of voting for McCain for each unit change in the independent variable, holding the other independent variables constant at 0 , and the change in probability of voting for McCain as one goes from the minimum value to the maximum value of the independent variable, holding the other independent variables constant at their mean values.

To assess the differential effects of stereotypes and racial resentment in the South and non-South I use conditional coding (Wright 1976; Aistrup 2010a). The coding of these four conditional variables is straightforward. For example, RacialResents is coded the value of the racial resentment index for Southern respondents and 0 for non-Southern respondents, whereas RacialResent $_{\mathrm{N}}$ is coded the value of the racial resentment index for nonSouthern respondents and 0 for Southern respondents. The same is also done with the index for racially biased stereotypes. For those interested, the following endnote explains the interpretation of conditional coefficients. ${ }^{5}$ The formal logit model tested is: 
$\ln \left\{\frac{\operatorname{Pr}(\text { McCainVT }=1 \mid x)}{1-\operatorname{Pr}(M c C a i n V T=1 \mid x)}\right\}=1 \mathrm{n} \Omega(x)=\beta_{0}+\beta_{1}$ South +

$\beta_{2}$ Hispanic $+\beta_{3}$ PartyID $+\beta_{4}$ Ideology $+\beta_{5}$ BushApproval +

$\beta_{6}$ Age $+\beta_{7}$ Education $+\beta_{8}$ ChurchAttend $+\beta_{9}$ RacialResent $_{S}+$

$\beta_{10}$ RacialResent $_{N}+\beta_{11}$ Stereotypes $_{S}+\beta_{12}$ Stereotypes $_{N}$

The first two hypotheses tested are:

Hypothesis 1: Voters with higher levels of racial stereotypes and racial resentment are more likely to support McCain.

Hypothesis 2: The impact of racial stereotypes and racial resentment will be greater in the South than in the non-South.

Given these hypotheses, I expect that the coefficients $\beta_{9}$ RacialResent ${ }_{S}$ and $\beta_{10}$ RacialResent $_{\mathrm{N}}$ will be positive and significant. The key difference will be in the magnitude of the effect, which should be larger for $\beta_{9}$ RacialResents. This same type of pattern should also occur with

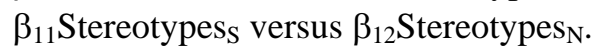

\section{Presidential Elections}

How much if at all did the electorate make the transition to a post-racial election? What influence did racially based attitudes have on the probability of voting for McCain over Obama? Are there any regional patterns for the racial attitude variables? Table 2 shows the findings from this analysis. ${ }^{6}$

In short, the white electorate did not make the transition to a post-racial electorate and there is a regional pattern to the impact of racial attitudes. First, the Southern dummy variable is statistically significant. After controlling for the effects of the other independent variables, being a white in the South increased the probability of supporting McCain by .192. As the aggregate statistics suggest, there was a predisposition in the South toward supporting McCain over Obama.

Second, racially biased stereotypes among whites in the non-South do not significantly effect the odds of supporting McCain, but this is not the case for stereotypes held by whites in the South. Each unit change toward stereotypes unfavorable to blacks increases the odds of voting for McCain by a factor of $\left(\mathrm{e}^{(.845+1.093)}\right) 6.94$. Even accounting for the fact that most respondents are in the middle of this index, the effect of racially biased stereotypes in the South is robust. Racial resentment, on the other hand, has a positive and significant effect in both regions. Even though the effect 
Table 2. Logit Analysis Predicting McCain vs. Obama Using Stereotypes and Racial Resentment and Controlling for Region, ANES 2008 Panel Survey

\begin{tabular}{|c|c|c|c|c|c|}
\hline Variables & Coefficient & $\mathrm{Z}$ & $\mathrm{P}>|\mathrm{z}|$ & $\begin{array}{c}\text { Logged } \\
\text { Odds }\end{array}$ & $\begin{array}{c}\text { Min to } \\
\text { Max }\end{array}$ \\
\hline South & 0.845 & 2.602 & 0.009 & 2.327 & 0.192 \\
\hline Hispanic & -1.298 & -1.343 & 0.179 & 0.273 & -0.310 \\
\hline Party ID & 0.622 & 6.644 & 0.000 & 1.863 & 0.722 \\
\hline Ideology & 0.510 & 3.652 & 0.000 & 1.665 & 0.642 \\
\hline Bush Approval & 1.399 & 4.745 & 0.000 & 4.051 & 0.520 \\
\hline Age & 0.012 & 1.327 & 0.184 & 1.012 & 0.212 \\
\hline Education & -0.081 & -0.665 & 0.506 & 0.922 & -0.078 \\
\hline Church Attend & 0.154 & 2.330 & 0.020 & 1.166 & 0.217 \\
\hline Stereo South & 1.093 & 2.701 & 0.007 & 2.983 & 0.847 \\
\hline Stereo North & 0.172 & 0.672 & 0.501 & 1.188 & 0.265 \\
\hline Resent South & 0.213 & 2.325 & 0.020 & 1.237 & 0.770 \\
\hline Resent North & 0.195 & 3.502 & 0.000 & 1.215 & 0.720 \\
\hline Constant & 0.562 & 2.265 & 0.024 & & \\
\hline Number of obs & $=116$ & & & & \\
\hline Wald chi $^{2}(12)$ & $=308$. & & & & \\
\hline Prob $>$ chi $^{2}$ & $=0.00$ & & & & \\
\hline Log pseudolikelihood & od $=-281$ & 478 & & & \\
\hline Pseudo $\mathrm{R}^{2}$ & $=0.65$ & & & & \\
\hline ML (Cox-Snell) $\mathrm{R}^{2}$ & $=.592$ & & & & \\
\hline \multicolumn{6}{|c|}{ Statistically Significant Coefficients Bolded $(P<.05)$} \\
\hline
\end{tabular}

is slightly greater in the South than in the non-South, the main differences between the regions appear to be small. Figure 1 graphically shows this by translating these logit coefficients for racial resentment into probabilities of supporting McCain for white respondents from the non-South and South who are independent, moderate, neither approve or disapprove of Bush, and are at the mean levels of the other independent variables. I focus on these voters because they are in the middle of the political spectrum. The line with the diamond symbols represents the probability of supporting McCain for a given level of racial resentment. Consistent with the findings noted above, racial resentment's impact on southern respondents is slightly steeper and starts off with a higher probability of supporting McCain when compared to their non-Southern counterparts (dots). This difference is mostly a function of the significant effect of the southern dummy variable. The contrast between the regions weakens at the high ends of the index. 
Figure 1. Moderate Independents by Region

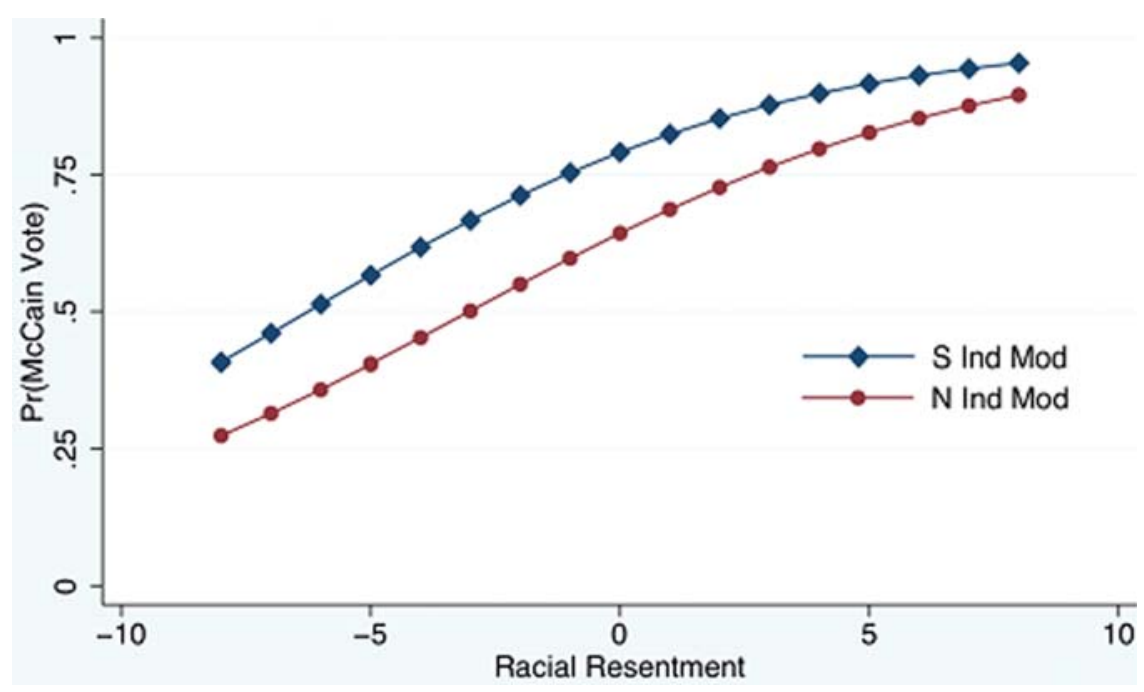

Third, similar to Piston's (2010) analysis, I find support for Sniderman and Carmines' (1997) contention that Democrats are more affected by racial attitudes than Republicans. They note that Republicans uniformly vote for Republican candidates no matter how racist they are. On the other hand, Democrats who hold racially biased opinions are conflicted over their position on racial issues and their Democratic leanings. These voters are more likely to stray from their party identification. Figure 2 illustrates that both southern and non-South Democrats with low levels of racial resentment have about a 10 percent probability of voting for McCain, whereas Democrats with the highest levels of racial resentment range from 60 percent for nonSouth Democrats to over 75 percent for southern Democrats. By contrast, both southern and non-South Republicans with low levels of racial resentment have about a 75 percent probability of voting for McCain. At the high end of the index the probability for both types of Republicans is very close to 1.7

Fourth, the effects of the other independent variables mostly correspond with normal expectations for presidential elections in the 21st Century. For example, party identification, ideology, and approval of President Bush significantly determine support for McCain. Each unit change toward GOP partisanship increases the odds of voting for McCain by a factor of 1.863. For ideology, factor is 1.665 , for church attendance, 1.166, while for approval of Bush, a whopping 4.051. The coefficients for age, education and Hispanics are insignificant at the .05 level. 
Figure 2. Democrats and Republicans by Region

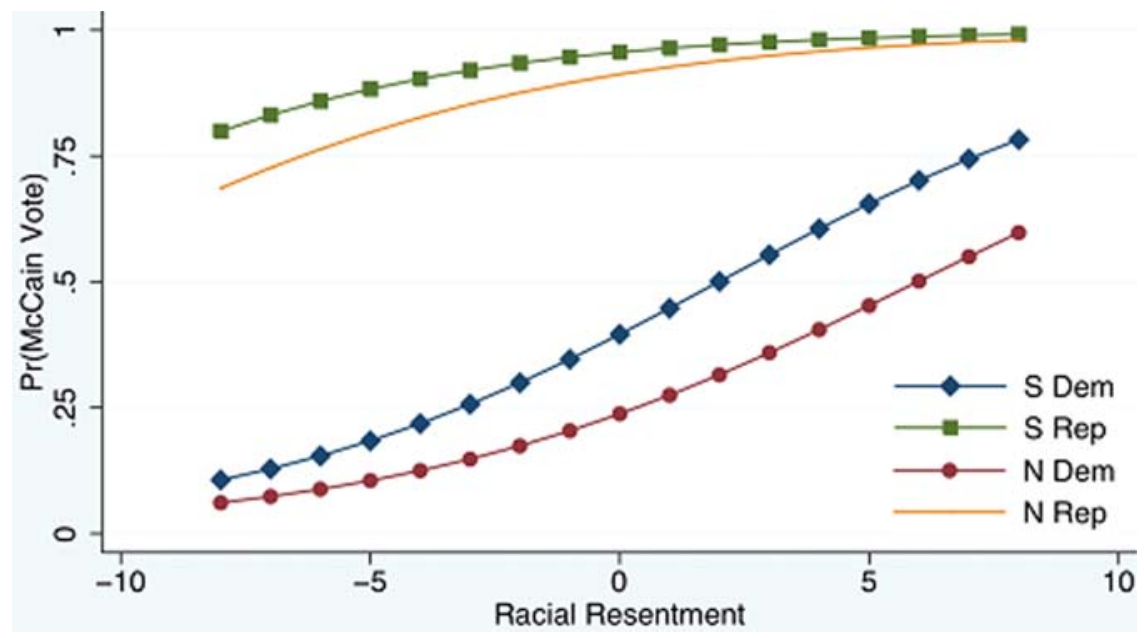

One striking aspect of these findings is how important racial resentment is for influencing presidential voting behavior even after removing its shared variance with racially biased stereotypes and controlling for ideology. Moderates in the non-South with the lowest level of racial resentment have less than a 30 percent probability of supporting McCain. On the other hand, moderates in the non-South with the highest level of racial resentment have almost a 90 percent probability of supporting McCain. Given this finding, I did additional analyses to assess the robustness of the coefficients. Even after including a host of other types of racially oriented questions (for example feeling thermometers for blacks, Hispanics, and Muslims) the coefficients for racial resentment do not deviate from the findings shown in Table 2. As noted earlier, racially biased stereotypes have a greater influence in the South than non-South. These results partially replicate Piston's (2010). The coefficient for racially biased stereotypes is significant for only the South, instead of the entire U.S. The most likely reason for this deviation in findings is the differences in question wording and format. Unfortunately, the Panel Study did not include a battery of stereotype questions in the same format as the face to face ANES survey. If so, I would be able to develop a more systematic and rigorous explanation.

The final research question is to assess the extent to which these results are isolated to the case of Barack Obama in 2008 versus any other election. In examining this same type of question, Piston found that since the 1992 presidential election, racially biased stereotypes had a significant effect 
in only the 2008 presidential election. He also demonstrated that racially biased stereotypes influenced only Obama's feeling thermometer score, but not those of Joseph Biden's, Bill Clinton's, or the Democratic Party's. Understanding the significance of these results would be enhanced if the relationship between voting and racially based attitudes were confined solely to the presidential level in 2008 versus other elective offices. To explore this possibility, I turn my attention to the congressional elections, focusing on contested U.S. House races in 2008. If the effects of racial attitudes became systemic in 2008, then one would expect to find a similar relationship at the U.S. House level as the presidential level. Thus, I hypothesize:

Hypothesis 3: Voters with higher levels of racial stereotypes and racial resentment are more likely to support Republican U.S. House candidates.

Hypothesis 4: The impact of racial stereotypes and racial resentment will be greater in the South than in the non-South.

\section{U.S. House Elections}

Similar to the presidential analysis, I use logistic regression, where a vote for a GOP candidate is coded 1, and a vote for a Democratic candidate is coded 0 . Respondents in uncontested races or who cast their ballots for independent or third party candidates are excluded from the analysis. Any respondent who is a member of a district represented by a member of the Congressional Black Caucus is also excluded. These respondents are not included because while it may be noteworthy to determine if racial attitudes influence the voting behavior of whites in these districts, there are too few cases to conduct a viable analysis. Excluding these respondents avoids any confounding influence that the race of the candidate may have on the analysis. In addition to using the same list of independent variables from the first analysis, I also include an additional control variable representing incumbency, where Democratic incumbency is coded +1 , open seats are coded 0 , and Republican incumbency is coded -1 (effects coding). The logistic model is:

$\ln \left\{\frac{\operatorname{Pr}(G O P V T=1 \mid x)}{1-\operatorname{Pr}(G O P V T=1 \mid x)}\right\}=\ln \Omega(x)=\beta_{0}+\beta_{1}$ South +

$\beta_{2}$ Hispanic $+\beta_{3}$ PartyID $+\beta_{4}$ Ideology $+\beta_{5}$ BushApproval +

$\beta_{6}$ Age $+\beta_{7}$ Education $+\beta_{8}$ ChurchAttend $+\beta_{9}$ RacialResent $_{S}+$ $\beta_{10}$ RacialResent $_{N}+\beta_{11}$ Stereotypes $_{S}+\beta_{12}$ Stereotypes $_{N}$ 


\section{Table 3. Logit Analysis Predicting Republican Vote in U.S. House Elections Using Stereotypes and Racial Resentment and Controlling for Region, ANES 2008 Panel Survey}

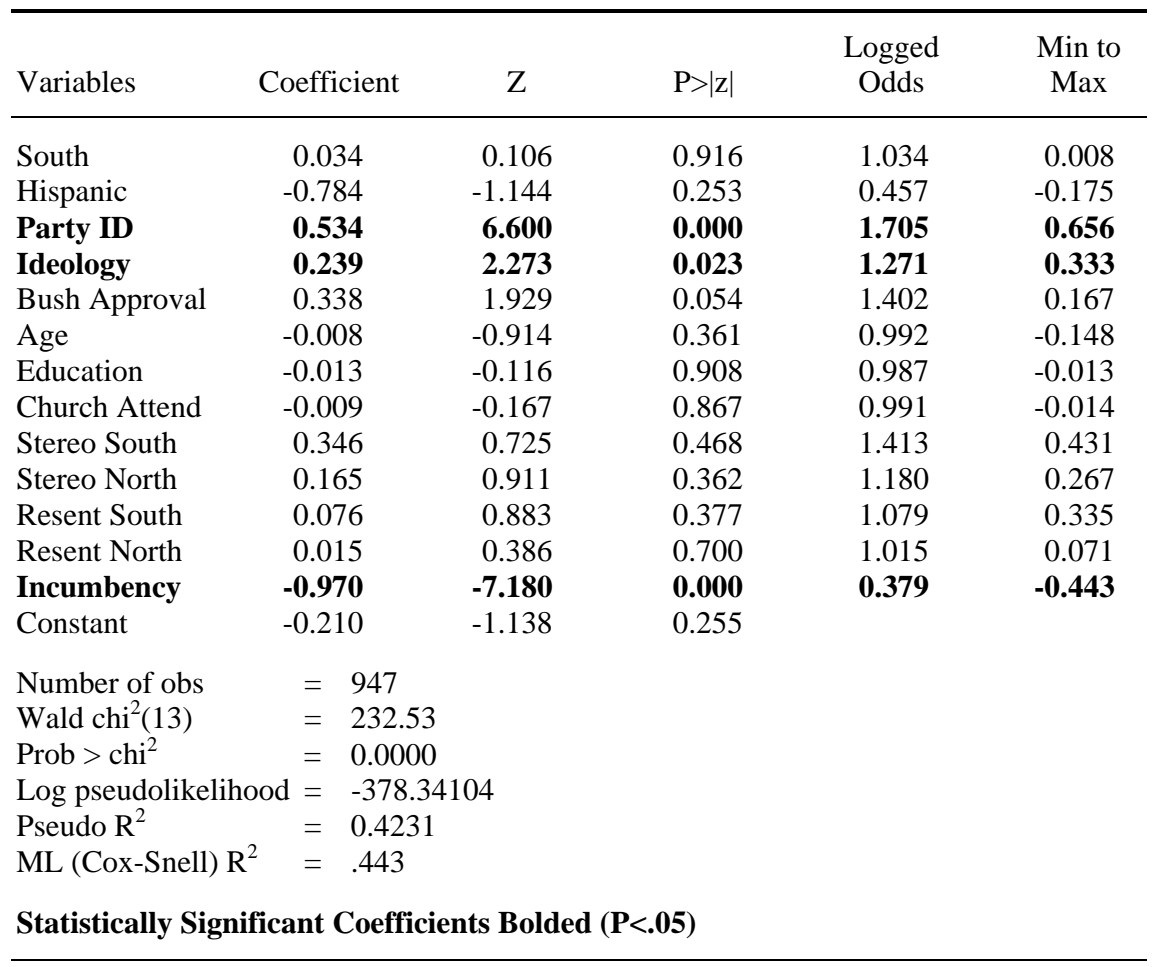

Table 3 shows that the direct effects of racial resentment on U.S. House contests are statistically insignificant in the South and non-South. In addition, both regional measures of racially biased stereotypes are insignificant. The only variables that predict GOP U.S. House votes are party identification, ideology, and incumbency. Of the rest of the variables, only approval of President Bush approaches statistical significance.

Suffice to say that I reject both hypothesis 3 and hypothesis 4 . The implications of this analysis are that racially based attitudes need a trigger to directly influence voting behavior. Even within the context of the same election, the influences of racially based attitudes were confined to the presidential level, where Obama's African American heritage provided the stimulus. The U.S. House level remained immune from these considerations in the South and non-South. The three Rs only apply to the presidential level in 2008. These findings replicate Piston's (2010). 


\section{Conclusion}

None of this should take away from what was an historic event; the election of the U.S.'s first African American president. This fact, in and of itself, is a testament to the progress the U.S. has made in exorcizing the demons of slavery and racial discrimination. However, not all of these demons have been removed.

Resentment: The findings show that voters in the U.S. have yet to completely remove themselves from these racial considerations. Racial resentment taps into whites' attitudes regarding why some African Americans struggle with achieving economic parity within American society. Even though some may find fault with this indicator as being too closely embedded into conservative ideology, its resilience in predicting white voting behavior when an African American is on the ballot remains impressive (Citrin et al. 1990). Indeed, even after controlling for partisanship and ideology, the findings show that racial resentment shaped the probabilities of voting for McCain for voters in the middle of the political spectrum and Democrats in both regions.

Interestingly, these analyses suggest that the direct effects of racial resentment on voting are largely confined to presidential level in 2008. This finding corresponds to the previous research that underscores that racial resentment's direct impact on voting is triggered when racial cues are present. Whereas in Louisiana in the 1990s, David Duke was the activating agent, the race of the candidate is triggering mechanism in the case of Bradley in California in the late 1960s through the 1980s and Obama in 2008. ${ }^{8}$

Racism and Regionalism: The findings also speak to the controversy regarding the distinctiveness of the South, especially as it applies to racism. The most striking finding is that the influence of racially biased stereotypes is still concentrated in the South and not anywhere else, debunking, at least in this one instance, the recent literature suggesting that the old South had "gone with the wind" (Aistrup 2010a; Shafer and Johnston 2006). At this stage, the effects of racism appear to be an isolated incident associated with the election of Obama. However, given the "shellacking" the Democrats took in the mid-term elections and the fact that almost all previously reliable mid-term election models were off in their predictions by 20 or more U.S. House seats (see October 2010 edition of PS: Political Science and Politics), a viable hypothesis is that racism and resentment may have contributed to the GOP landslide, working through the presidential approval ratings of Obama and helping to motivate the GOP faithful to participate at very high levels. 
Finally, did Obama miss his landslide in 2008 as suggested by LewisBeck et al. (2010)? The findings here suggest that Obama paid a price for his race through racial resentment in the non-South and through both resentment and racially biased stereotypes in the South. Whether racial issues lower his national landslide by as much as 5 percent is difficult to determine with these data. Nonetheless, one thing is for certain: Basic attitudes about race helped to shape the election of Obama in 2008 and there were regional disparities associated with this outcome.

\section{NOTES}

${ }^{1}$ Reverend Wright was Obama's pastor in Chicago who made some rather racially inflammatory remarks from behind the pulpit, which were recorded and available to the public on DVD.

${ }^{2}$ Ironically, studies of statewide contests show when media outlets emphasize the "first black to win" story, it is counterproductive to black candidates' ability to win (Jeffries 2002; Reeves 1997).

${ }^{3}$ The subtlest form of racial prejudice is what psychologist call implicit racism. This subconscious form of racism is measured by the attributions that respondents make when shown a variety of pictures of different races, including African Americans. Piston in dismissing implicit racism notes that many have taken issue with this indicator on "grounds, ranging from the argument that conscious intent is required for prejudice to exist (Arkes and Tetlock 2004) to concerns about the variability and stability in the IAT, the most common measure of implicit racism (Blanton and Jaccard 2008)" (Piston 2010, 434).

4,'The 2008-2009 ANES Panel Study is a telephone-recruited Internet panel with two cohorts. The first cohort was recruited in late 2007 using random-digit-dialing (RDD) methods common to high-quality telephone surveys. Prospective respondents were offered $\$ 10$ per month to complete surveys on the Internet for 30 minutes each month for 21 months, from January 2008 through September 2009. Those without a computer and Internet service were offered a free web appliance, MSNTV2, and free Internet service for the duration of the study. The second cohort was recruited the same way in the summer of 2008 and asked to join the panel beginning in September 2008.To minimize panel attrition and conditioning effects, only 10 of the 21 monthly surveys were primarily about politics. Other surveys were about a variety of non-political topics, using questions not written by ANES. The panelists answered political questions prepared by ANES in January, February, June, September, October, and November, 2008, and in January, May, July, and August 2009" (ANES 2010).

${ }^{5}$ Interpretation of the coefficients of the conditional model is straightforward. For example, to calculate the logged odds of McCain vote in the non-South for a given level of racial resentment, the equation is $\beta_{0}+\beta_{10}$ RacialResent $_{\mathrm{N}}$ (holding all other independent variables constant at 0 ), whereas for the South, the equation is $\beta_{0}+\beta_{1}$ South + $\beta_{9}$ RacialResents. Wright notes that a conditional model can be viewed as two regression analyses where separate coefficients are estimated for each group within one equation (1976, 359-60). Please note that the conditional model is mathematically equivalent to the 
interaction model, however, the coefficients from the conditional model are easier to interpret.

${ }^{6}$ Given the possibility for collinearity among the list of independent variables, which may confound the effects of the racial attitude variables, I ran multicollinearity diagnostics (Variance Inflation Factor, and Conditional Index). All tests showed that there are no issues with multicollinearity. The average VIF $=1.28$ and the sum Condition Index $=15.4$. This suggests that the following analysis should be able to determine the independent influences of racial attitudes on presidential vote choice, controlling for the effects of the other independent variables.

${ }^{7}$ I ran separate logistic regression analyses for Democrats and Republicans, confirming these patterns.

${ }^{8}$ In many respects, the consistency of this construct's influence on voting behavior over several decades is astounding.

\section{REFERENCES}

Abramowitz, Alan, and Kyle L. Saunders. 1998. Ideological Realignment of the U.S. Electorate. Journal of Politics 60:634-652.

Aistrup, J.A. 2010a. Southern Political Exceptionalism? Presidential Voting in the South and Non-South. Social Science Quarterly 91:906-927.

Aistrup, J.A., E.F. Kisangani, and R.L. Piri. 2010b. The Legacy of Race in 2008. Pp. 233250 in Presidential Elections in the South: Putting 2008 in Political Context, eds. B.D. Kapluck, R.P. Steed and L.W. Moreland. Boulder, CO: Lynne Rienner Publishers.

Aistrup, Joseph A. 1996. Southern Strategy Revisited: Southern Republican Top-Down Advancement. Lexington: The University Press of Kentucky.

Allport, G.W. 1988. The Nature of Prejudice. Cambridge, MA: Perseus Books Publishers.

American National Election Studies. 2010. ANES 2008-2009 Panel Study [dataset]. Stanford University and the University of Michigan [producers and distributors].

American National Election Studies. 2009. American National Election Study, 2008: Preand Post-Election Survey ICPSR25383-v1. Technical report Ann Arbor, MI: Interuniversity Consortium for Political and Social Research [distributor].

Ansolabehere, Stephen, and Charles Stewart III. 2009. Amazing Race. Boston Review, January/February. http://www.bostonreview.net/BR34.1/ansolabehere_stewart.php.

Arkes, H.A., and P.E. Tetlock. 2004. Attributions of Implicit Prejudice, or 'Would Jesse Jackson Fail the Implicit Association Test?' Psychological Inquiry 15:53-58.

Bass, Jack, and Walter DeVries. 1976. The Transformation of the Southern Electorate. Basic Books, Inc.

Beck, P.A., and P. Lopatto. 1982. The End of Southern Distinctiveness. In Contemporary Southern Political Attitudes and Behavior, eds. L.W. Moreland, T.A. Baker, and R.P. Steed. New York: Praeger.

Black, Earl, and Merle Black. 1987. Politics and Society in the South. Cambridge, MA: Harvard University Press.

Black, Earl, and Merle Black. 2002. The Rise of Southern Republicans. Cambridge, MA: Harvard University Press.

Blanton, H., and J. Jaccard. 2008. Unconscious Racism: A Concept in Pursuit of a Measure. Annual Review of Sociology 34:277-297. 
Brewer, Mark D., and Jeffrey M. Stonecash. 2001. Class, Race Issues, and Declining White Support for the Democratic Party in the South. Political Behavior 23:131155.

Bullock, Charles S., Donna Hoffman, and Ronald K. Gaddie. 2005. The Consolidation of the White Southern Congressional Vote. Political Research Quarterly 58:231-243.

Bullock, Charles S., Donna R. Hoffman, and Ronald Keith Gaddie. 2006. Regional Variations in the Realignment of American Politics, 1944-2004. Social Science Quarterly 87(3):494-518.

Campbell, A., P.E. Converse, W.E. Miller, and D. Stokes. 1960. The American Voter. New York: Wiley.

Campbell, Angus. 1966. A Classification of Presidential Elections. In Elections and the Political Order, eds. Angus Campbell, Philip E. Converse, Warren E. Miller, and Donald E. Stokes. New York: John Wiley.

Carmines, Edward G., and Harold W. Stanley. 1990. Ideological Realignment in the Contemporary South: Where have all the conservatives gone. In The Disappearing South: Studies in Regional Change and Continuity, eds. Robert P. Steed, Laurence W. Moreland, and Tod Baker. Tuscaloosa: University of Alabama Press.

Citrin, Jack, Donald P. Green, and David O. Sears. 1990. White Reactions to Black Candidates: When Does Race Matter? Public Opinion Quarterly 54:76-96.

Colleau, Sophie M., Kevin Glynn, Steven Lybrand, Richard M. Merelman, Paula Mohan, and James E. Wall. 1990. Symbolic Racism in Candidate Evaluation: An Experiment. Political Behavior 12:385-402.

Cotter, Patrick, and J.G. Stovall. 1990. The Conservative South? American Politics Quarterly 18:103-119.

Cotter, Patrick R., Stephen D. Shaffer, and David A. Breaux. 2006. Issues, Ideology, and Political Opinions in the South. Pp. 219-240 in Writing Southern Politics, eds. Robert P. Steed and Laurence W. Moreland. Lexington: University Press of Kentucky.

Cowden, Jonathan A. 2001. Southernization of the Nation and Nationalization of the South: Racial Conservativsm, Social Welfare and White Partisans in the United States, 1956-92. British Journal of Political Science 31:277-301.

Edsall, T.B., and M.D. Edsall. 1992. Chain Reaction. New York: W.W. Norton and Co.

Feig, Douglas G. 1990. Dimensions on Southern Public Opinion on Prayer in Schools. In The Disappearing South? Studies of Regional Change and Continuity, eds. Robert P. Steed, L. W. Moreland, and Tod A. Baker. Tuscaloosa: University of Alabama Press.

Feldman, Stanley, and Leonie Huddy. 2005. Racial Resentment and White Opposition to Race-Conscious Programs: Principles or Prejudice? American Journal of Political Science 49:168-183.

Fiorina, Morris P. 1981. Retrospective Voting in American National Elections. New Haven, CT: Yale University Press.

Frederick, K.A., and J. L. Jeffries. 2009. A Study in African American Candidates for High-Profile Offices. Journal of Black Studies 39:689-718.

Green, John C., Lyman A. Kellstedt, Corwin E. Smidt, and James L. Guth. 2002. The Soul of the South: Religion and Southern Politics at the Millenium. In The New Politics of the Old South: An Introduction to Southern Politics, 2nd ed., eds. Charles S. Bullock III, and Mark J. Rozell. Lanham, MD: Rowman and Littlefield.

Green, John C., Mark J. Rozell, and Clyde Wilcox. 2003. The Christian Right in American Politics: Marching to the Millennium. Washington, DC: Georgetown University Press. 
Henry, P.J., and D.O. Sears. 2002. The Symbolic Racism Scale. Political Psychology 23: 253-283.

Highton, Benjamin. 2004. White Voters and African American Candidates for Congress. Political Behavior 26:1-25.

Howell, Susan E. 1994. Racism, Cynicism, Economics, and David Duke. American Politics Quarterly 22:190-207.

Jaccard, James. 2001. Interactive Effects in Logistic Regression. Thousand Oaks, CA: Sage Publications.

Jeffries, J. L. 1999. U.S Senator Edward W. Brooke and Governor L. Douglas Wilder Tell Political Scientists How Blacks Can Win High-Profile Statewide Office. PS: Political Science and Politics 32:538-587.

Jeffries, Judson L. 2002. Press Coverage of Black Statewide Candidates: The Case of Douglas L. Wilder of Virginia. Journal of Black Studies 32:673-697.

Key, V.O., Jr. 1949. Southern Politics in the State and Nation. New York: Knopf.

Kinder, Donald R., and David O. Sears. 1981. Prejudice and Politics: Symbolic Racism versus Racial Threats to the Good Life. Journal of Personality and Social-Psychology 40:414-431.

Kinder, Donald R., and Tali Mendelberg. 2000. Individualism Reconsidered: Principles and Prejudice in Contemporary American Opinion. In Radicalized Politics: The Debate about Racism in America, eds. David O. Sears, James Sidanius, and Lawrence Bobo. Chicago, IL: University of Chicago.

Klarner, Carl. 2008. The Racial Threat Hypothesis in the 2008 Presidential Election. Unpublished manuscript.

Knuckey, Jonathan. 2005. Racial Resentment and the Changing Partisanship of Southern Whites. Party Politics 11:5-28.

Knuckey, Jonathan. 2006. Explaining Recent Changes in the Partisan Identifications of Southern Whites. Political Research Quarterly 59:57-70.

Lewis-Beck, Michael S., Charles Tien, and Richard Nadeau. 2010. Obama's Missing Landslide: A Racial Cost? PS: Political Science and Politics 43:69-76.

Long, J. Scott, and Jeremy Freese. 2006. Regression Models for Categorical Dependent Variables Using Stata, 2nd ed. College Station, TX: Stata Press Publication.

McConahay, John B. 1986. Modern Racism, Ambivalence, and the Modern Racism Scale. In Prejudice, Discrimination, and Racism, eds. John Dovidio and Samuel L. Gaertner. Orlando, FL: Academic Press.

McConahay, John B., and J.C. Hough. 1976. Symbolic Racism. Journal of Social Issues 32:23-46.

McKee, Seth C. 2009. Republican Ascendency in Southern U.S. House Elections. Boulder, CO: Westview Press.

Miller, Warren, and Merrill J. Shanks. 1996. The New American Voter. Cambridge, MA: Harvard University Press.

Oldfield, Duane M. 1996. The Christian Right in the Presidential Nominating Process. In In Pursuit of the White House-How We Choose Our Presidential Nominees, ed. William G. Mayer. Chatham, NJ: Chatham House.

Peffley, M., and T. Shields. 1996. Whites' Stereotypes of African Americans and Their Impact on Contemporary Political Attitudes. In Research in Micropolitics, eds. M.X. Delli-Carpini, L. Huddy, and R. Shapiro. Stamford, CT: JAI Press.

Piston, Spencer. 2010. How Explicit Racial Prejudice Hurt Obama in the 2008 Election. Political Behavior 32:431-452.

Reeves, Keith. 1997. Voting Hopes or Fears? White Voters, Black Candidates, and Racial Politics in America. New York: Oxford University Press. 
Rice, T.W., W.P. McLean, and A.J. Larsen. 2002. Southern Distinctiveness Overtime: 1972-2000. American Review of Politics 23:193-220.

Schneider, Paige L. 1998. Factionalism in the Southern Republican Party. American Review of Politics 19:129-148.

Schuman, H., C. Steeh, and L. Bobo. 1997. Racial Attitudes in America: Trends and Interpretations. Revised, eds. Cambridge, MA: Harvard University Press.

Schuman, H., C. Steeh, L. Bobo, and M. Krysan. 2005. Racial Attitudes in America: Trends and Interpretations, rev. ed. Cambridge, MA: Harvard University Press.

Schuman, Howard. 2000. The Perils of Correlation, the Lure of Labels, and the Beauty of Negative Results. In Radicalized Politics: The Debate about Racism in America, eds. David O. Sears, James Sidanius, and Lawrence Bobo. Chicago, IL: University of Chicago.

Sears, David O. 1988. Symbolic Racism. In Eliminating Racism: Profiles in Controversy, eds. P. Katz and D.A. Taylor. New York, NY: Plenum.

Sears, David O., and Donald R. Kinder. 1971. Racial Tensions and Voting in Los Angeles. In Los Angeles: Viability and Prospects for Metropolitan Leadership, eds. W.Z. Hirsch. New York: Praeger.

Shafer, Byron E., and Richard Johnston. 2006. The End of Southern Exceptionalism: Class, Race, and Partisan Change in the Post War South. Cambridge, MA: Harvard University Press.

Shaffer, Stephen D., Stacie Berry Pierce, and Steven A. Kohnke. 2000. Party Realignment in the South: A Multi-Level Analysis. American Review of Politics 21:129153.

Smith, Oran P. 1997. The Rise of Baptist Republicans. New York: New York University Press.

Sniderman, P.M., and E.G. Carmines. 1997. Reaching Beyond Race. Cambridge, MA: Harvard University.

Sniderman, Paul M., and Michael G. Hagen. 1985. Race and Inequality: A Study in American Values. Chatham, NJ: Chatham House.

Sniderman, Paul M., and Thomas Piazza. 1993. The Scar of Race. Cambridge, MA: Harvard University Press.

Sniderman, Paul M., and Edward H. Stiglitz. 2008. Race and the Moral Character of the Modern American Experience. The Forum 6(4):Article 1.

Sniderman, Paul M., and Philip E. Tetlock. 1986. Symbolic Racism: Problems of Motive Attribution in Political Analysis. Journal of Social Issues 42:129-150.

Stoker, Laura. 1998. Understanding Whites' Resistance to Affirmative Action: The Role of Principled Commitments and Racial Prejudice. In Perception and Prejudice: Race and Politics in the United States, eds. J. Hurwitz and M. Peffley. New Haven, CT: Yale University Press.

Sundquist, J.L. 1983. The Dynamics of the Party System. Revised edition. Washington, DC: The Brookings Institute.

Terkildsen, Nayda. 1993. When White Voters Evaluate Black Candidates: The Processing Implications of Candidate Skin Color, Prejudice, and Self-Monitoring. American Journal of Political Science 37:1032-1053.

Valentino, Nicholas A., and David O. Sears. 2005. Old Times There Are Not Forgotten: Race and Partisan Realignment in the Contemporary South. American Journal of Political Science 49:672-688.

Virtanen, Simo V., and Leonie Huddy. 1998. Old-Fashioned Racism and New Forms of Racial Prejudice. Journal of Politics 60:311-332. 


\section{4 | Joseph A. Aistrup}

Wright, G., R.E. Erikson, and J.P. McIver. 1985. Measuring State Partisanship and Ideology with Survey Data. Journal of Politics 47:469-489.

Wright, Gerald C. 1976. Linear Models for Evaluating Conditional Relationships. American Journal of Political Science 20:349-373. 